\title{
Sistem Peramalan Indeks Harga Konsumen (IHK) Menggunakan Metode Double Exponential Smoothing
}

\author{
${ }^{1}$ Siti Nurul Afiyah, ${ }^{2}$ Dhiky Kurnia Wijaya \\ ${ }^{1,2}$ STMIK Asia Malang \\ 1.noeroelafy@gmail.com, ${ }^{2}$ kurniadiki90@gmail.com
}

\begin{abstract}
ABSTRAK. Indeks Harga Konsumen (IHK) adalah nomor indeks yang mengukur harga rata-rata dari barang dan jasa yang dikonsumsi oleh rumah tangga (household). IHK sering digunakan untuk mengukur tingkat inflasi suatu negara dan juga sebagai pertimbangan untuk penyesuaian gaji, upah, uang pensiun, dan kontrak lainnya. Tujuan penulisan tugas akhir ini untuk memberikan gambaran kedepan kepada pemerintah dalam memberikan suatu kebijakan yang akan datang.Data yang digunakan dalam penelitian ini adalah Indeks Harga Konsumen (IHK) di Indonesia pada bulan Januari 2010 sampai dengan Desember 2016. Dari data IHK bulan Januari 2010 sampai dengan Desember 2016 dilakukan proses perbaikan terus - menerus pada objek peramalan terbaru dengan menitik beratkan pada penurunan prioritas secara exponential pada objek pengalaman yang lebih tua. Dari hasil plot data, termasuk jenis data trend yang lebih cocok mengguanakan double exponential smoothing.Untuk melakukan pengujian peramalan maka dilakukan dengan cara perhitungan percentage error dan mean absolut percentage error. Setelah melalui proses peramalan dengan menggunakan metode double exponential smoothing, didapat hasil peramalan Indeks Harga Konsumen (IHK) di Indonesia pada bulan Januari 2017 adalah 127.24 pada alpha 0.9 dengan MAPE 1.24. MAPE terkecil antara alpha 0.1 sampai 0.9 maka akan digunakan sebagai peramalan.
\end{abstract}

Kata Kunci: Peramalan, double exponential smoothing, IHK

ABSTRACT. The Consumer Price Index (CPI) is an index number that measures the average price of goods and services consumed by households. CPI is often used to measure the inflation rate of a country and also as a consideration for the adjustment of salaries, wages, pensions, and other contracts. The purpose of this research is to provide a future picture to the government in providing a policy that will come. The data used in this final project is the Consumer Price Index (CPI) in Indonesia from January 2010 to December 2016. From the CPI data from January 2010 to December 2016, a continuous improvement process in the latest forecasting object emphasizing on the decline of Priority exponential on the older object experiences. From the data plot, including the type of data trend, the more suitable method is using double exponential smoothing. To do the forecasting test is done by calculating the percentage error and the mean absolute percentage error. After going through the process of forecasting using double exponential smoothing method, the result of forecasting Consumer Price Index (CPI) in Indonesia in January 2017 is 127.24 at alpha 0.9 with MAPE(Mean Absolute Percentage Error) 1.24. The smallest MAPE between alpha $0<\alpha<1$ will be used as a forecast.

Keywords: Forecast, double exponential smoothing, Consumer Price Index (CPI).

\section{PENDAHULUAN}

Indeks harga merupakan barometer kondisi ekonomi secara umum. Dengan indeks harga, para pemimpin atau manager dapat mengelola data-data yang ada sehingga dapat mengetahui perkembangan usaha atau kegiatan yang dilakukan, seperti untuk mengetahui faktor-faktor yang mempengaruhi kemajuan ekonomi, sebagai ukuran tingkat kemajuan ekonomi, atau sebagai alat bagi pemerintah untuk menetapkan kebijaksanaan harga (menaikkan atau menurunkan harga). Dalam hal ini, proses kenaikan harga secara umum dan terus-menerus disebut sebagai inflasi. Beberapa indeks harga yang sering digunakan untuk mengukur inflasi antara lain adalah Indeks Harga Konsumen (IHK). 
Indeks Harga Konsumen (IHK) merupakan indikator umum tingkat inflasi di Indonesia yang dihitung dan diumumkan ke publik setiap bulannya oleh Badan Pusat Statistik (BPS). IHK memberikan informasi mengenai perkembangan rata-rata perubahan harga sekelompok barang atau jasa yang pada umumnya dikonsumsi oleh rumah tangga dalam suatu kurun waktu tertentu (Syahyuti).

Peramalan Indeks Harga Konsumen (IHK) dengan segala bentuk analisis dan informasi yang dihasilkan guna membantu dan menunjang kegiatan sosial ekonomi di Indonesia, khususnya di daerahdaerah. Hasil peramalan IHK dilihat pada beberapa media. Namun, saat ini masih banyak yang belum tahu bagaimana cara memperkirakan IHK tersebut.

Peramalan yang dilakukan umumnya berdasarkan pada data masa lampau maupun data saat ini, yang dianalisis dengan menggunakan cara-cara tertentu. Data masa lampau dikumpulkan, dipelajari, dianalisis dan dihubungkan dengan gerakan waktu. Selanjutnya dari analisis tersebut, dicoba memperkirakan suatu nilai pada masa yang akan datang. Hasil dari peramalan tidak akan mendapatkan nilai kebenaran $100 \%$, akan tetapi ada nilai kesalahan yang dihasilkan. Meskipun hasil dari peramalan tidak selalu tepat, tetapi terbukti bahwa peramalan telah banyak digunakan dan membantu dengan baik dalam berbagai bidang sebagai dasar-dasar perencanaan, pengawasan, dan pengambilan keputusan (kebijakan). Salah satunya adalah peramalan IHK itu sendiri.

Adapun metode yang dapat memberi solusi dari permasalahan yang diuraikan di atas, yaitu metode exponential smoothing. Beberapa metode yang ada di exponential smothing adalah single exponential smoothing, double exponential smoothing, dan triple exponential smoothing. Single exponential smoothing digunakan apabila data yang dianalisa bersifat stasioner atau nilai rata - ratanya konstan, dan apabila pola datanya menunjukkan perubahan yang naik atau turun maka double exponential smoothing sedangkan untuk pola data yang bersifat musiman bisa menggunakan metode triple exponential smoothing. Karena besarnya pengaruh Indeks Harga Konsumen (IHK) terhadap laju inflasi ekonomi yang selanjutnya akan berdampak besar terhadap maju tidaknya perekonomian di Indonesia, serta kelebihan metode exponential smoothing yang bisa digunakan untuk semua pola data. Dari data IHK pada Badan Pusat Statistika (BPS) yang cenderung naik termasuk pola data trend yang lebih cocok menggunakan metode double exponential smoothing.

\section{METODE PENELITIAN}

\subsection{Analisa Data}

Dalam penelitian ini jenis data yang digunakan adalah time series (runtun waktu) dari tahun 2010 2016. Sumber data diperoleh dari Badan Pusat Statistika (BPS) dan data tersebut meliputi data IHK (Indeks Harga Konsumen). Data IHK akan diramal menggunakan data masa lalu yang akan dianalisa untuk memperkirakan suatu nilai pada masa yang akan datang. Berikut data IHK (Indeks Harga Konsumen) dapat dilihat pada Tabel 1:

Tabel 1. Data IHK Tahun 2010 sampai 2016

\begin{tabular}{|l|c|}
\hline \multicolumn{1}{|c|}{ Bulan-Tahun } & IHK \\
\hline Januari-2010 & 118.01 \\
\hline Februari-2010 & 118.36 \\
\hline Maret-2010 & 118.19 \\
\hline April-2010 & 118.37 \\
\hline Mei-2010 & 118.71 \\
\hline Juni-2010 & 119.86 \\
\hline Juli-2010 & 121.74 \\
\hline Agustus-2010 & 122.67 \\
\hline September-2010 & 123.21 \\
\hline Oktober-2010 & 123.29 \\
\hline November-2010 & 124.03 \\
\hline Desember-2010 & 125.17 \\
\hline Januari-2011 & 126.29 \\
\hline Februari-2011 & 126.46 \\
\hline Maret-2011 & 126.05 \\
\hline April-2011 & 125.66 \\
\hline Mei-2011 & 125.81 \\
\hline Juni-2011 & 126.5 \\
\hline
\end{tabular}




\begin{tabular}{|c|c|}
\hline Juli-2011 & 127.35 \\
\hline Agustus-2011 & 128.54 \\
\hline September-2011 & 128.89 \\
\hline Oktober-2011 & 128.74 \\
\hline November-2011 & 129.18 \\
\hline Desember-2011 & 129.91 \\
\hline Januari-2012 & 130.9 \\
\hline Februari-2012 & 130.96 \\
\hline Maret-2012 & 131.05 \\
\hline April-2012 & 131.32 \\
\hline Mei-2012 & 131.41 \\
\hline Juni-2012 & 132.23 \\
\hline Juli-2012 & 133.16 \\
\hline April-2010 & 118.37 \\
\hline Agustus-2012 & 134.43 \\
\hline September-2012 & 134.45 \\
\hline Oktober-2012 & 134.67 \\
\hline November-2012 & 134.76 \\
\hline Desember-2012 & 135.49 \\
\hline Januari-2013 & 136.88 \\
\hline Februari-2013 & 137.91 \\
\hline Maret-2013 & 138.78 \\
\hline April-2013 & 138.64 \\
\hline Mei-2013 & 138.6 \\
\hline Juni-2013 & 140.03 \\
\hline Juli-2013 & 144.63 \\
\hline Agustus-2013 & 146.25 \\
\hline September-2013 & 145.74 \\
\hline Oktober-2013 & 145.87 \\
\hline November-2013 & 146.04 \\
\hline Desember-2013 & 146.84 \\
\hline Januari-2014 & 110.99 \\
\hline Februari-2014 & 111.28 \\
\hline Maret-2014 & 111.37 \\
\hline April-2014 & 111.35 \\
\hline Mei-2014 & 111.53 \\
\hline Juni-2014 & 112.01 \\
\hline Juli-2014 & 113.05 \\
\hline Agustus-2014 & 113.58 \\
\hline September-2014 & 113.89 \\
\hline Oktober-2014 & 114.42 \\
\hline November-2014 & 116.14 \\
\hline Desember-2014 & 119 \\
\hline Januari-2015 & 118.71 \\
\hline Februari-2015 & 118.28 \\
\hline Maret-2015 & 118.48 \\
\hline April-2015 & 118.91 \\
\hline Mei-2015 & 119.50 \\
\hline Juni-2015 & 120.14 \\
\hline Juli-2015 & 121.26 \\
\hline Agustus-2015 & 121.73 \\
\hline September-2015 & 121.67 \\
\hline Oktober-2015 & 121.57 \\
\hline November-2015 & 121.82 \\
\hline Desember-2015 & 122.99 \\
\hline
\end{tabular}




\begin{tabular}{|l|l|}
\hline Januari-2016 & 123.62 \\
\hline Februari-2016 & 123.51 \\
\hline Maret-2016 & 123.75 \\
\hline April-2016 & 123.19 \\
\hline Mei-2016 & 123.48 \\
\hline Juni-2016 & 124.29 \\
\hline Juli-2016 & 125.15 \\
\hline Agustus-2016 & 125.13 \\
\hline September-2016 & 125.41 \\
\hline Oktober-2016 & 125.59 \\
\hline September-2016 & 125.41 \\
\hline Oktober-2016 & 125.59 \\
\hline November-2016 & 126.18 \\
\hline Desember-2016 & 126.71 \\
\hline
\end{tabular}

Dari data pada Tabel 1 akan dijadikan plot grafik supaya dapat dianalisa, untuk mengetahui apakah pola data tersebut adalah plot data horizontal, trend, musiman, atau siklis. Plot data tren ada dua yaitu trend naik atau trend turun. Plot data IHK tahun 2010- 2016 digambarkan pada Gambar 1.

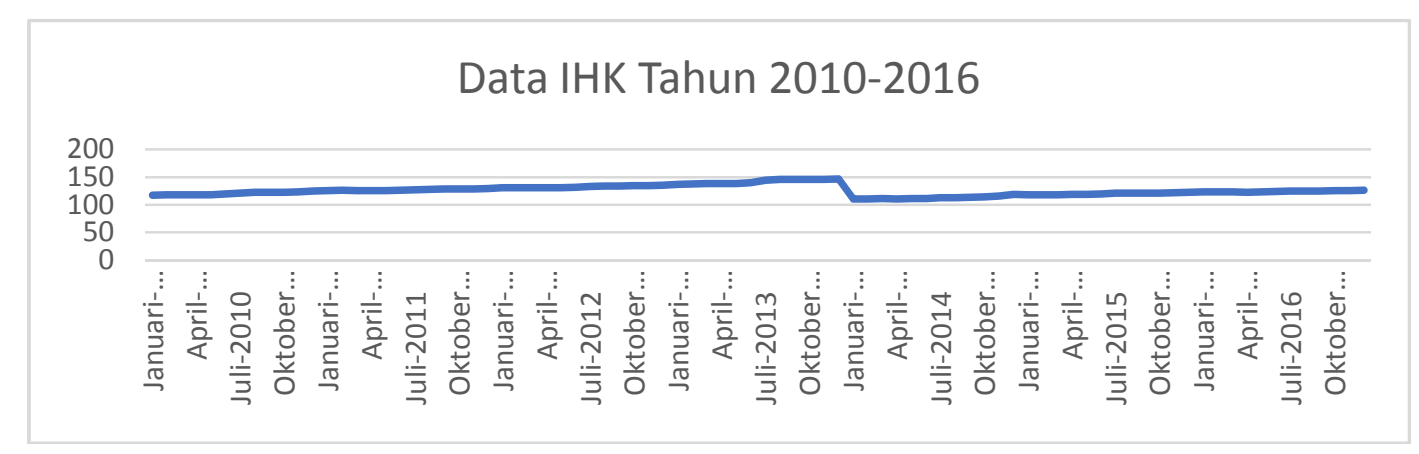

Gambar 1. Plot Data Indeks Harga Konsumen (IHK) Tahun 2010- 2016

Dari Gambar 1 terlihat bahwa plot data IHK tahun 2010- 2016 terus mengalami kenaikan pada bulan januari 2010 hingga bulan november 2013 dan sempat mengalami penurunan pada bulan november 2013 hingga januari 2014. Untuk selanjutnya pada bulan januari 2014 hingga desember 2016 mengalami kenaikan. Sehingga pola data tersebut bisa dikatakan mengikuti pola data trend naik meskipun juga sempat mengalami trend turun dalam kurun waktu 3 bulan berturut-turut. Pola data trend bisa diramalkan menggunakan metode peramalan double exponential smoothing. Data yang akan diramalkan adalah data IHK pada bulan januari tahun 2017.Yang mana dalam pencarian hasil peramalannya menggunakan data IHK mulai bulan januari 2010 sampai bulan desember 2016 terakhir.

\subsection{Double Exponential Smoothing and MAPE (Mean Absolute Percentage Error)}

Dalam penelitian ini, dilakukan peramalan IHK mengunakan metode double exponential smoothing, dan berikut pada Gambar 2 merupakan flowchart dari metode tersebut. 


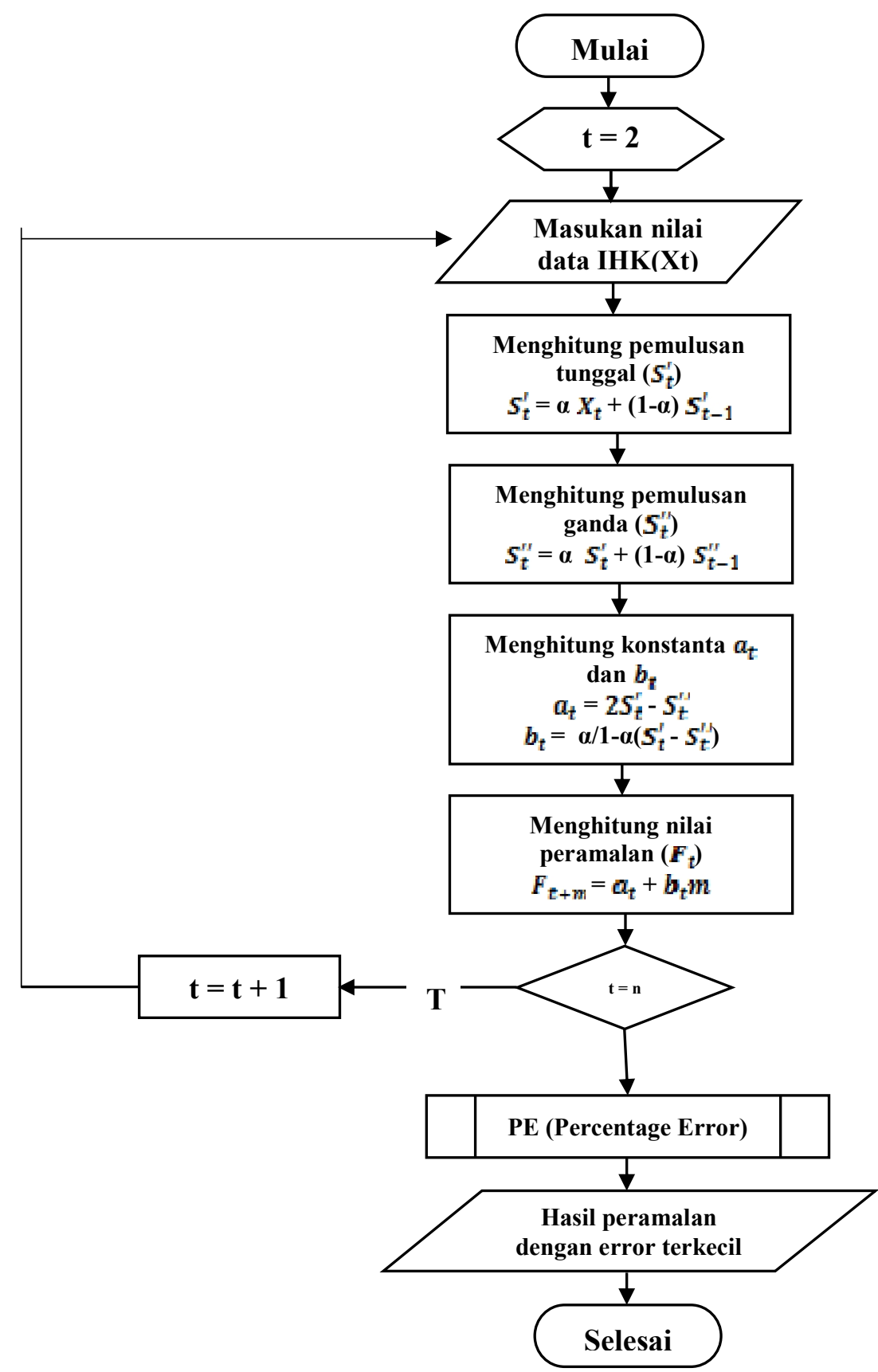

Gambar 2. Flowchart Metode Double Exponential Smoothing

Setelah perhitungan menggunakan metode double exponential smoothing, langkah selanjutnya adalah menghitung rata-rata kesalahan menggunakan rumus MAPE yang mana akan diambil kesimpulan peramalan dengan hasil nilai MAPE terkecil. Dimana rumus dari MAPE adalah:

$$
M A P E=\sum_{t=1}^{n} \frac{\left|\frac{X_{t}-F_{t}}{X_{t}}\right|}{n} \cdot 100
$$

Keterangan :

$X_{t}=$ data sebenarnya pada periode ke-i

$F_{t}=$ nilai ramalan pada periode ke-i

$n=$ banyaknya periode waktu 


\section{HASIL DAN PEMBAHASAN}

\subsection{Interface}

Tampilan aplikasi peramalan IHK yang dibangun, dibuat untuk memudahkan dalam pengoperasian dan pemahaman bagi pengguna. Terdapat beberapa halaman pada aplikasi peramalan IHK menggunakan metode double exponential smoothing pada BPS (Badan Pusat Statistika) yaitu, halaman pengolahan data IHK dan halaman double exponential smoothing.

\subsubsection{Halaman Login}

Pada halaman login berfungsi untuk mengecek username dan password pada tabel login. Apabila login berhasil akan masuk ke dalam halaman utama. Berikut desain halaman login pada Gambar 3.

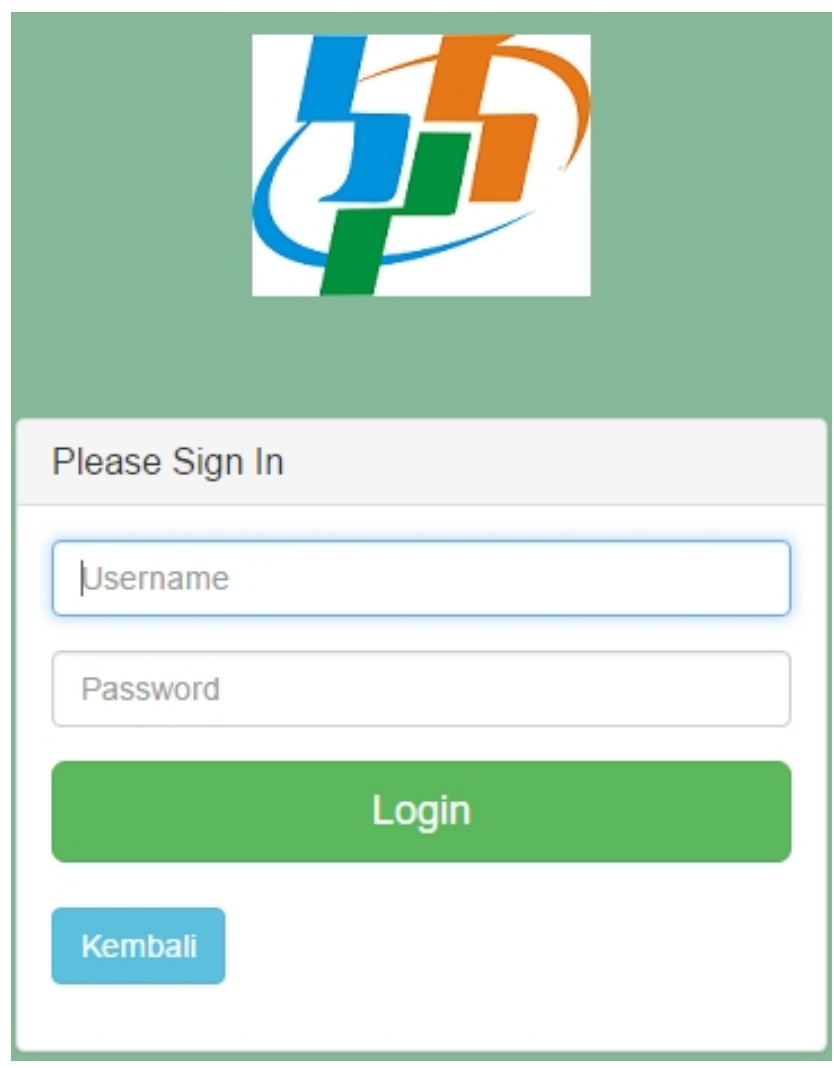

Gambar 3. Halaman Login

\subsubsection{Halaman Utama}

Pada halaman menu utama digunakan untuk menghubungkan menu-menu yang ada pada sistem. Menu - menu tersebut adalah menu data IHK, peramalan alpha 0.1-0.9, menu manual alpha dan grafik. Tampilan halaman utama dapat dilihat pada Gambar 4.

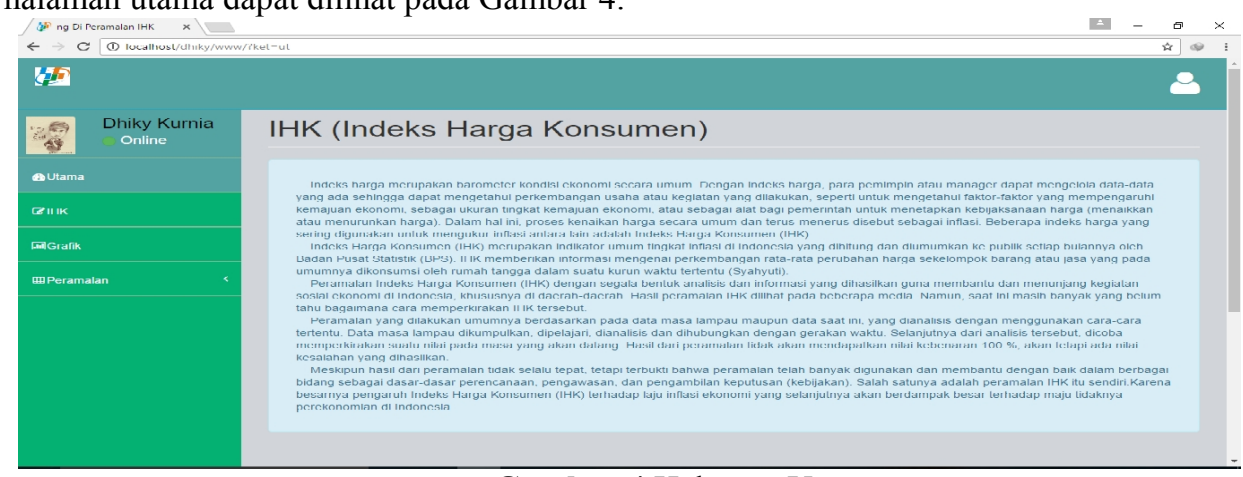

Gambar 4 Halaman Utama 


\subsubsection{Halaman Data IHK}

Pada halaman data IHK digunakan untuk mengolah data IHK meliputi save, update, delete. Menu save digunakan untuk menambah data IHK, Menu update digunakan untuk merubah data IHK dan menu delete digunakan untuk menghapus data IHK. Tampilan halaman data IHKdapat dilihat pada Gambar 5.

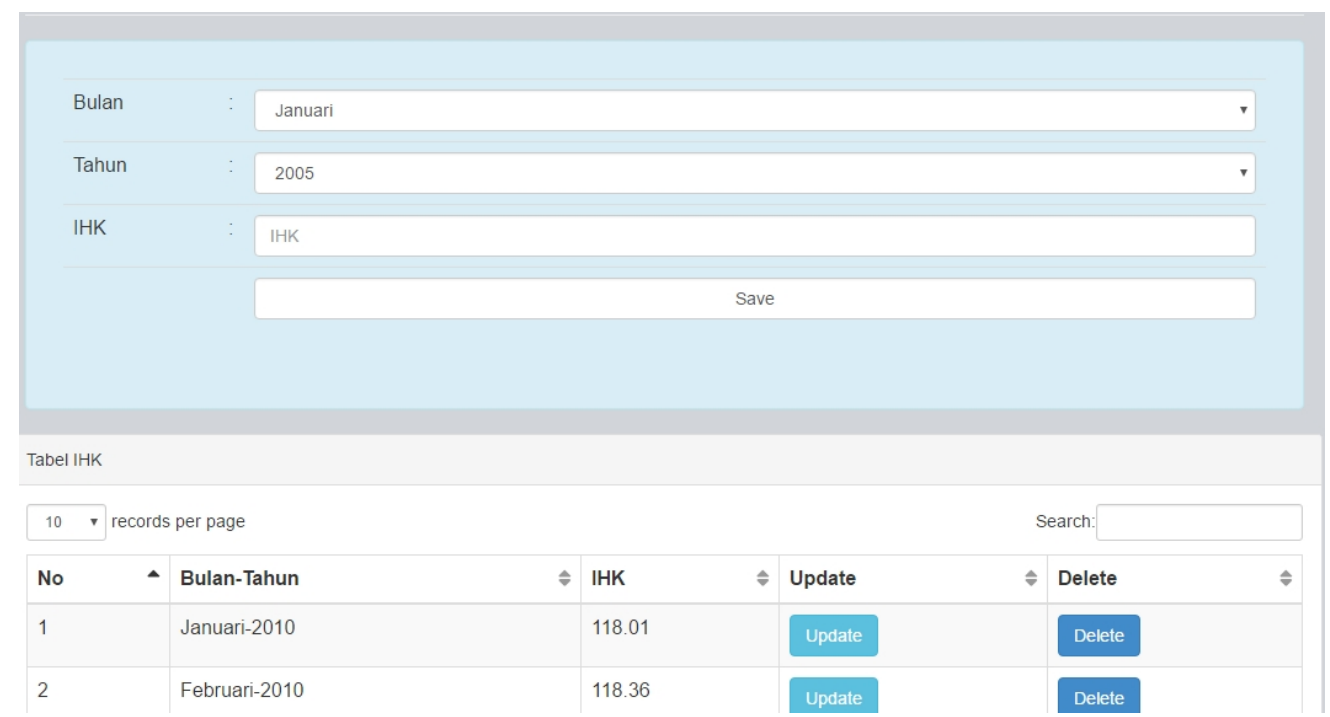

Gambar 5. Halaman Data IHK

\subsubsection{Grafik Data IHK}

Pada halaman grafik Data IHK digunakan untuk membuat suatu plot data, yaitu plot data asli IHK dan plot data hasil peramalan IHK. Pada Gambar 6 sampai 8 menggambarkan beberapaplot data asli berwarna merah dan plot data hasil ramalan berwarna biru. Pada Gambar 6 sampai 8 menunjukkan testing grafik dari beberapa nilai alpha $0.1,0.5$ dan 0.9 .

Pada Gambar 6 adalah plot data dengan alpha 0.1 dengan MAPE terbesar dengan nilai 3.08. Pada gambar 6 terlihat banyak perbedaan pada titik - titik tertentu dengan data asli IHK.

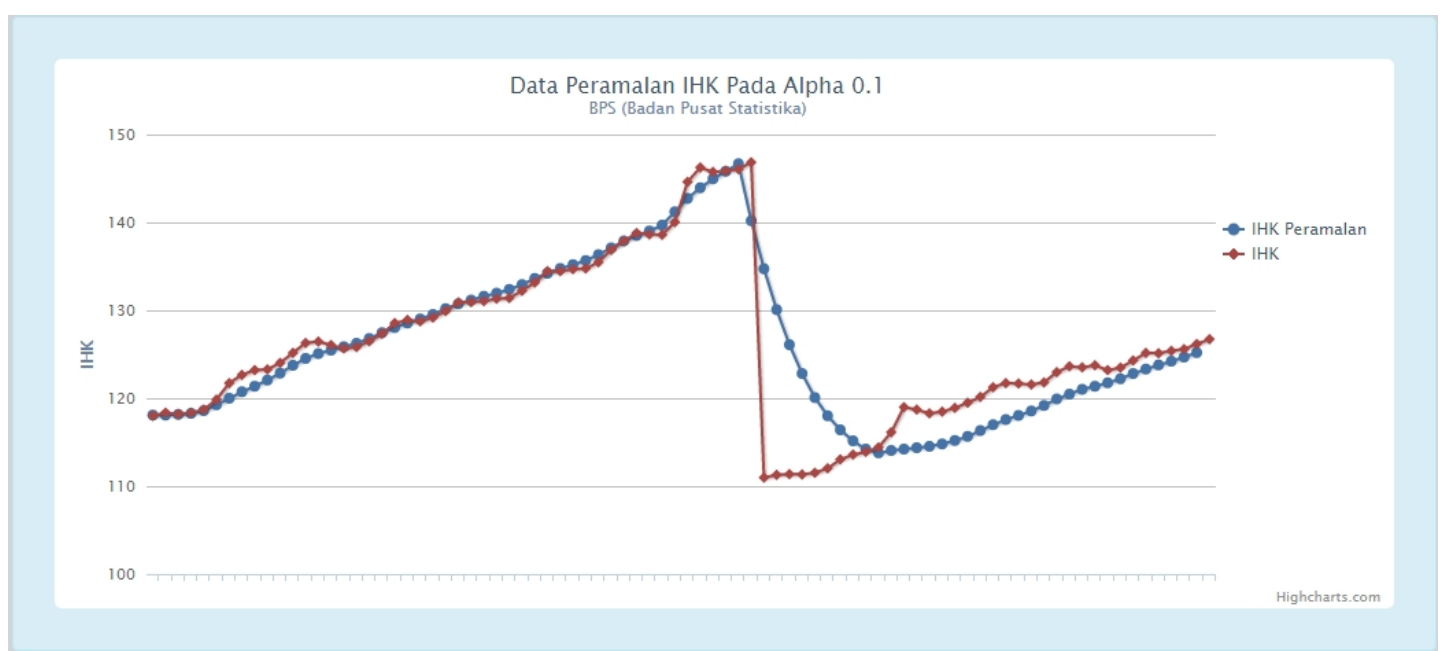

Gambar 6. Plot Data Peramalan IHK Alpha 0.1

Pada Gambar 7 adalah plot data dengan alpha 0.5 dengan perbedaan yang mulai mendekati dengan data asli IHK dari pada alpha 0.1. 


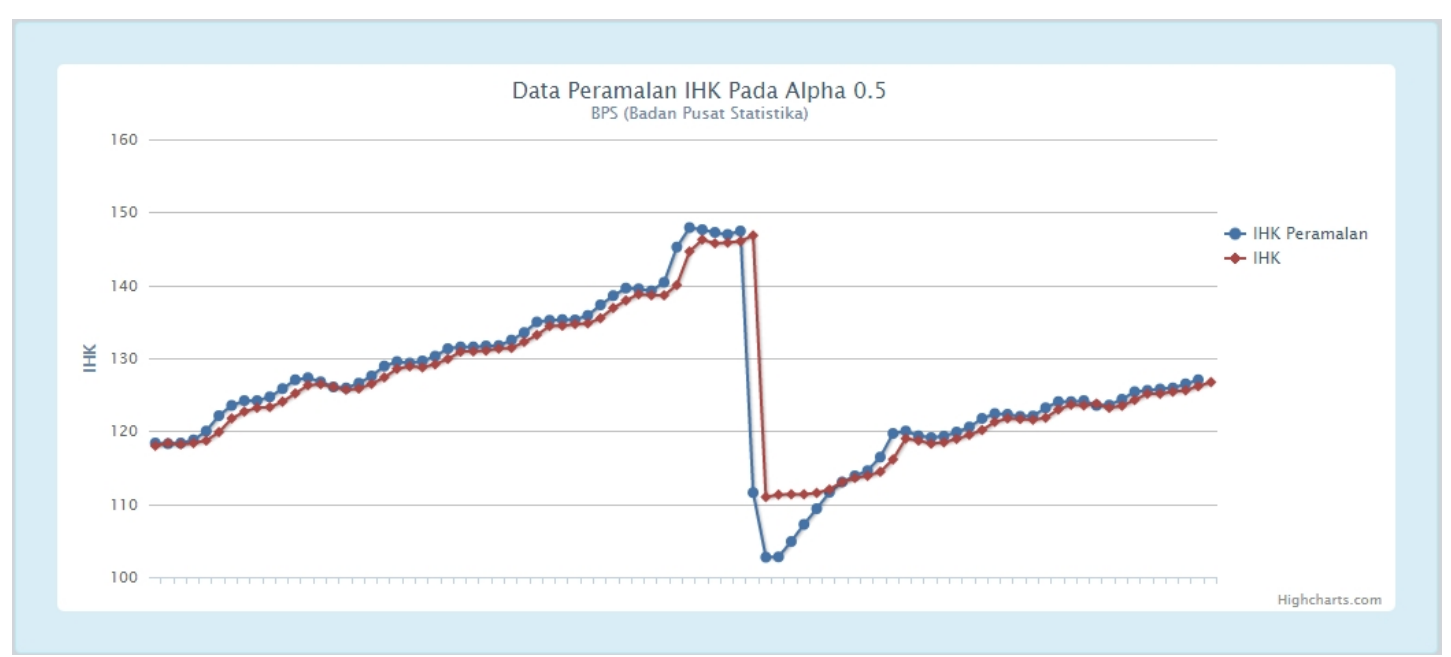

Gambar 7. Plot Data Peramalan IHK Alpha 0.5

Pada Gambar 8 adalah plot data perbandingan antara data asli IHK dengan data hasil peramalan IHK dengan alpha terbaik yaitu 0.9 dengan MAPE 1.21 dengan sedikit perbedaan dari pada alpha 0.5 . Pada Gambar 8 memiliki sedikit perbedaan dengan data asli IHK.

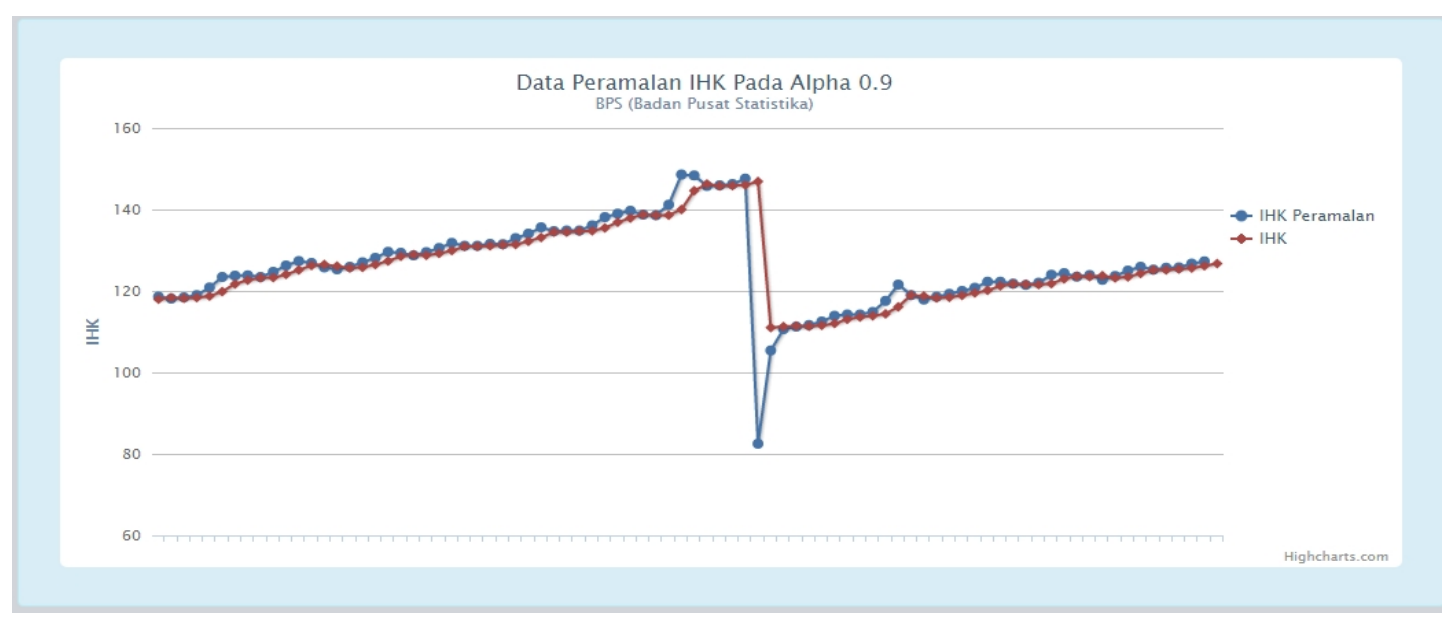

\subsection{Hasil Peramalan}

Gambar 8. Plot Data Peramalan IHK Alpha 0.9

Dari hasil ramalan menggunakan data IHK mulai bulan januari 2010 hingga data IHK bulan desember 2016 didapatkan MAPE terkecil yaitu 1.21 pada alfa 0.9. Hasil peramalan tersebut untuk meramalkan data IHK pada bulan januari 2017 yaitu sebesar 127.25. Tampilan hasil peramalan dari setiap alpha ditunjukkan pada Gambar 9. 


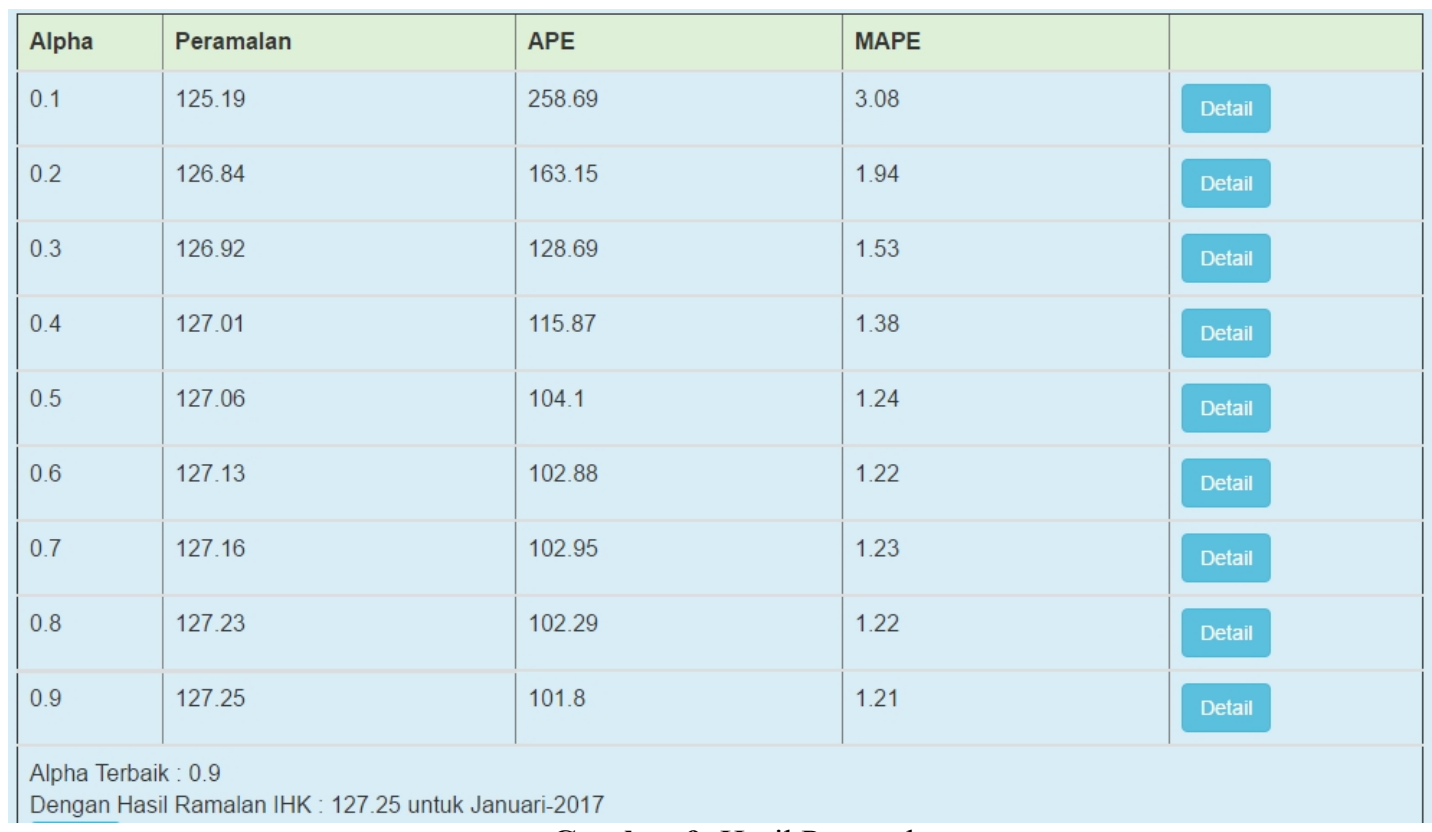

\section{KESIMPULAN}

Gambar 9. Hasil Peramalan

Berdasarkan hasil analisa dan pembahasan yang telah dilakukan dalam penelitian ini, maka dapat ditarik kesimpulan sebagai berikut:

1. Sistem dapat memberikan informasi IHK dengan menganalisa tingkat kesalahan terkecil pada hasil ramalan dari alpha 0.1 sampai dengan alpha 0.9 .

2. Pada hasil peramalan ini nilai MAPE terkecil terdapat pada alfa 0.9 dengan nilai MAPE 1.21 untuk bulan januari 2017.

3. Pola trend yang dihasilkan dari peramalan IHK pada BPS ( Badan Pusat Statistika) adalah pola naik

\section{DAFTAR PUSTAKA}

Kusuma, J, M.A. 2000. Statistik Teori dan Aplikasi Edisi 6 Jilid 1. Erlangga: Jakarta.

Makridakis, S. 1999. Metode dan Aplikasi Peramalan Edisi ke-2.Bina Aksara: Jakarta.

Nasution, H. and Arman. .2003. Perencanaan dan Pengendalian Produksi, Guna Wijaya : Jakarta

Sumayang. 2003. Dasar-Dasar Manajemen Produksi dan Operasi, Salemba Empat : Jakarta.

Yamit,Z.1999. Manajemen Persediaan. Ekonisia : Yogyakarta 